\title{
Inhibitory Effects of Sialic Acid- or $N$-Acetylglucosamine-Specific Lectins on Histamine Release Induced by Compound 48/80, Bradykinin and a Polyethylenimine in Rat Peritoneal Mast Cells
}

\author{
Koji Matsuda, Akinao Niitsuma, Masaatsu K. Uchida and Tamiko Suzuki-Nishimura* \\ Department of Molecular Pharmacology, Meiji College of Pharmacy, Tokyo 154, Japan \\ Received July 23, 1993 Accepted October 13, 1993
}

\begin{abstract}
The effects of seven lectins with various sugar-specificities on histamine release from rat peritoneal mast cells induced by non-immunologic stimuli were studied. The non-immunologic stimuli used were three basic secretagogues, compound $48 / 80$, bradykinin and $\mathrm{PEI}_{6}$ (polyethylenimine with a molecular weight of 600). In this study, we observed inhibition of the histamine release by Macckia amurensis mitogen and Solanum tuberosum agglutinin $\left(100 \mu \mathrm{g} / \mathrm{ml}\right.$ at $37^{\circ} \mathrm{C}$ for $\left.10 \mathrm{~min}\right)$, which are specific for sialic acid- $\alpha 2,3-$ $N$-acetyl galactosamine (Sia $\alpha 2,3 \mathrm{GalNAc}$ ) and $N$-acetyl glucosamine (GlcNAc) oligomers, respectively. The effects of Phytolacca americana mitogen and Sambucus sieboldiana agglutinin were different. Three lectins specific for mucin type oligosaccharides inhibited the histamine release induced by compound $48 / 80$ but not that induced by bradykinin or $\mathrm{PEI}_{6}$. Since bradykinin and $\mathrm{PEI}_{6}$ additively enhanced the histamine release induced by compound $48 / 80$, they partially shared the same signalling pathways. Glycoproteins with bisecting GlcNAc and Sia residues, as described previously (Jpn. J. Pharmacol. 57, 79-90, 1991), seemed to be one of the action sites for compound 48/80, bradykinin and $\mathrm{PEI}_{6}$. In addition to the direct activation of the pertussis toxin-sensitive $G$ proteins, we propose another mechanism of non-immunologic stimuli via specific glycoproteins on rat peritoneal mast cells. The apparent sugar residues involved were asparagine-linked oligosaccharides with Sia (especially Sia $\alpha 2,3 \mathrm{Gal}$ ), GlcNAc oligomers and/or bisecting GlcNAc.
\end{abstract}

Keywords: Mast cell, Histamine release, Lectin, Non-immunologic stimuli, Sugar-specificity

Rat peritoneal mast cells are a model system for the study of human skin mast cells as both rat peritoneal mast cells (connective tissue type) and human skin mast cells $\left(\mathrm{MC}_{\mathrm{TC}}\right)$ are activated in the presence of non-immunologic stimuli such as anaphylatoxin, compound $48 / 80$, substance $\mathrm{P}$, bradykinin and $\mathrm{PEI}_{6}(1-9)$. Unlike IgE-dependent activation, the activation by non-immunologic stimuli is independent of IgE receptors, extracellular calcium and phosphatidylserine (10), but is dependent on Gi-like G protein activation $(11-14)$. Compound $48 / 80$, substance

* To whom correspondence should be addressed.
$P$ and bradykinin are basic secretagogues. Since compound $48 / 80$, substance $P$ and bradykinin stimulate the GTPase activity of Gi $\alpha$ because of the interaction between these basic compounds and the negatively charged region of Gi $\alpha$ (15), they seemed to activate mast cells by direct G-protein activation, rather than by a receptor-dependent pathway (16).

Recently our group reported that a 10 -min incubation of rat peritoneal mast cells with WGA or PHA- $E_{4}$, but not with Con $\mathrm{A}$ or $\mathrm{PHA}_{4} \mathrm{~L}_{4}$, resulted in sugar-specific inhibition of the histamine release induced by compound 48/80, bradykinin and $\mathrm{PEI}_{6}(14,17)$. Glycoproteins were

Abbreviations used are: $\mathrm{PEI}_{6}$, polyethylenimine with a molecular weight of 600 ; $\mathrm{Gi}$, pertussis toxin-sensitive heterotrimeric $\mathrm{GTP}$-binding protein (an inhibitor of adenylate cyclase); WGA, wheat germ agglutinin; PHA- $\mathrm{E}_{4}$, phytohemagglutinin-E subunits; Con A, Concanavalin A; PHA- $\mathrm{L}_{4}$, phytohemagglutinin-L subunits; GlcNAc, $N$-acetyl glucosamine; Sia, sialic acid; GalNAc, $N$-acetyl galactosamine; MAM, Macckia amurensis mitogen; PWM, Phytolacca americana mitogen; SJA, Sophora japonica agglutinin; SSA, Sambucus sieboldiana agglutinin; STA, Solanum tuberosum agglutinin; ABA, Agaricus bisporus agglutinin; PNA, Arachis hypogaea agglutinin; SDS-PAGE, SDS-polyacrylamide gel electrophoresis; $\mathrm{IC}_{50}$, the concentration producing $50 \%$ inhibition; $\mathrm{IC}_{30}$, the concentration producing $30 \%$ inhibition. 


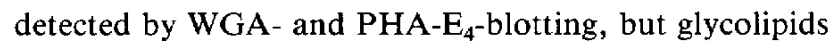
were not (17). Because WGA and PHA-E ${ }_{4}$ are GlcNAcspecific, especially the bisecting GlcNAc-specific lectins, glycoproteins with GlcNAc-residues seemed to be involved in the histamine releasing mechanisms, and the binding of WGA and PHA- $\mathrm{E}_{4}$ to the glycoproteins resulted in inhibition of histamine release. It was not likely that WGA and $\mathrm{PHA}-\mathrm{E}_{4}$ inhibited the interaction between basic secretagogues and $\alpha$ subunit of $\mathrm{Gi}(\mathrm{Gi} \alpha)$, because $\mathrm{Gi} \alpha$

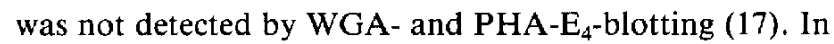
addition to the direct $\mathrm{G}$ protein activation (16), we propose another mechanism of non-immunologic mast cell activation via specific glycoproteins containing GlcNAc oligomers.

WGA and PHA- $\mathrm{E}_{4}$ also exhibit the ability to bind to a cluster of Sia and GalNAc, respectively. Therefore, in this study, we further examined the inhibitory effects of other lectins on histamine release induced by compound 48/80, bradykinin and $\mathrm{PEI}_{6}$. The seven lectins tested have different sugar specificities. MAM, PWM, SJA, SSA and STA bind asparagine-linked oligosaccharides; STA and PWM are specific for GlcNAc oligomers, and MAM and SSA are specific for Sia $\alpha 2,3 \mathrm{Gal}$ and Sia $\alpha 2,6 \mathrm{Gal}$, respectively (18-21). PWM also has an affinity to $N$-acetyllactosamine (22). ABA, PNA and SJA bind mucin type oligosaccharides with the Gal $\beta 1,3 \mathrm{GalNAc}$ residue $(22-24)$. SJA is characterized as a lectin having affinities both to mucin type and asparagine-linked oligosaccharides, and it inhibited histamine release mediated by $\operatorname{IgE}$ and compound $48 / 80$, but its inhibition was not sugar-specific because $10 \mathrm{mM}$ L-rhamnose, D-fucose, D-galactose and $\hat{\beta}$-lactose failed to protect the mast cells from inhibition by SJA $(24,25)$. Under our conditions, ABA, MAM, PNA, PWM, SSA and STA did not release histamine from rat peritoneal mast cells. We, therefore, examined the effects of these lectins on histamine release induced by non-immunologic stimuli from rat peritoneal mast cells.

\section{MATERIALS AND METHODS}

\section{Preparation of purified mast cells}

Mast cells from the peritoneal cavity of male SpragueDawley rats weighing $300-350 \mathrm{~g}$ were purified in HEPESbuffered Tyrode solution $(137 \mathrm{mM} \mathrm{NaCl}, 2.7 \mathrm{mM} \mathrm{KCl}$, $12 \mathrm{mM}$ HEPES, $1 \mathrm{mM} \mathrm{MgCl}, 0.3 \mathrm{mM} \mathrm{CaCl}_{2}, 5.6 \mathrm{mM}$ dextrose and $0.03 \%$ bovine serum albumin, $\mathrm{pH} 7.4$ ) by using Ficoll 400 (Pharmacia LKB Biotechnology AB, Uppsala, Sweden) as previously described (26). The purity of the mast cells in the final preparation was more than $90 \%$.

\section{Assay of histamine release from rat mast cells}

A $0.5-\mathrm{ml}$ sample of cell suspension $\left(2 \times 10^{4}\right.$ cells $)$ in
HEPES-buffered Tyrode solution was treated with and without lectins at $37^{\circ} \mathrm{C}$ for $10 \mathrm{~min}$. After treatment with lectins, the cells were then incubated with compound $48 / 80(0.3 \mu \mathrm{g} / \mathrm{ml})$, bradykinin $(50 \mu \mathrm{M})$ or $\mathrm{PEI}_{6}(3 \mu \mathrm{g} / \mathrm{ml})$ at $37^{\circ} \mathrm{C}$ for $10 \mathrm{~min}$. In the case of $\mathrm{A} 23187$-induced histamine release, the mast cells were challenged with A23187 $(1 \mu \mathrm{M})$ at $37^{\circ} \mathrm{C}$ for $15 \mathrm{~min}$. Ice-cold Hepes-buffered Tyrode solution $(2.3 \mathrm{ml})$ was added to terminate the reaction, and the mixture was centrifuged at $2,100 \times \mathrm{g}$ for $10 \mathrm{~min}$ at $4^{\circ} \mathrm{C}$. Released histamine in the supernatant was determined by the fluorometric assay of Shore et al. (27) Since A23187 interferes with the fluorometric assay, it was removed from the samples before the determination, as previously described (28). Histamine release was calculated as a percentage of the total cell content. Total histamine content was measured after treatment of the cells in the presence of $0.03 \mathrm{~N} \mathrm{HCl}$ at $100^{\circ} \mathrm{C}$ for $3 \mathrm{~min}$. Values for histamine release are given as the means \pm S.E. for several replicate experiments on different samples of pooled cells. The histamine release percentages induced by compound $48 / 80$, bradykinin and $\mathrm{PEI}_{6}$ at $37^{\circ} \mathrm{C}$ for $10 \mathrm{~min}$ were $58.4 \pm 1.7 \quad(\mathrm{n}=52), 43.5 \pm 1.5 \quad(\mathrm{n}=38)$, and $41.0 \pm 1.5$ $(n=41) \%$ of the total content, respectively. Spontaneous histamine release at $37^{\circ} \mathrm{C}$ for $10 \mathrm{~min}$ in the absence of basic secretagogues was $5.9 \pm 0.2(\mathrm{n}=100) \%$. No appreciable release of histamine was observed in the presence of tested lectins. The net histamine release $\%$ and the inhibitory effects of the lectins were calculated by the following equations, respectively:

Net histamine release $\%=($ histamine release $\%$ )

- (spontaneous histamine release $\%$ )

$\%$ Inhibition $=100-($ histamine release with lectin

- spontaneous release)/(histamine release without lectin

- spontaneous release) $\times 100$

\section{Treatment of neuraminidase}

Purified mast cells were treated with neuraminidase $\left(5 \times 10^{-4} \mathrm{U} / \mathrm{ml}\right)$ at $37^{\circ} \mathrm{C}$ for $1 \mathrm{hr}$ with gentle shaking. The cells were washed twice, resuspended in fresh HEPESbuffered Tyrode solution and exposed to A23187 (1 $\mu \mathrm{M})$ or compound $48 / 80(0.3 \mu \mathrm{g} / \mathrm{ml})$. There was no detectable protease activity in the neuraminidase preparation.

\section{SDS-PAGE and lectin-blotting}

SDS-PAGE and lectin-blotting were carried out as described previously (17). The cell pellets $\left(4 \times 10^{7}\right.$ cells $/ \mathrm{ml}$ ) were lysed in the presence of protease inhibitors. Protein extracts were fractionated by SDS-PAGE on $7.5 \%$ acrylamide gel and transferred to the nitrocellulose paper. Glycoproteins were detected with biotinyl-MAM and avidine-conjugated horseradish peroxidase after blocking with BSA. To examine the effect of neuraminidase, mast cells were incubated with neuraminidase $\left(10^{-2}\right.$ 
$\mathrm{U} / \mathrm{ml}$ ) at at $37^{\circ} \mathrm{C}$ for $1 \mathrm{hr}$, washed twice and then lysed in the presence of protease inhibitors.

\section{Statistical analyses}

Statistical significance of the histamine release $\%$, net histamine release $\%$ or $\%$ inhibition was evaluated by the unpaired Student's $t$-test, with $\mathrm{P}<0.05$ being regarded as significant.

\section{Chemicals}

Compound $48 / 80$ and bradykinin (acetate salt) were purchased from Sigma Chemical Co. (St. Louis, MO, USA). A23187 and neuraminidase (Clostridium perfringens) were from Calbiochem, Japan (Tokyo) and Boehringer-Mannheim Yamanouchi (Tokyo), respectively. $\mathrm{PEI}_{6}$ was a gift from Drs. N. Oku and M. Nango. ABA, MAM, PNA, PWM, SSA and biotinyl-MAM were purchased from the Honen Corp. (Tokyo). SJA and STA were from EY Laboratories (San Mateo, CA, USA). The avidin-conjugate of horseradish peroxidase was from Zymed (San Francisco, CA, USA).

\section{RESULTS}

Effects of MAM and STA on histamine release induced by compound $48 / 80$, bradykinin and $P E I_{6}$

The histamine release induced by compound $48 / 80$, bradykinin and $\mathrm{PEI}_{6}$ were inhibited by incubation of the cells with the Sia-specific lectin MAM for $10 \mathrm{~min}$ (Fig. 1).
$\mathrm{IC}_{50}$ values of MAM of histamine release induced by compound 48/80, bradykinin and $\mathrm{PEI}_{6}$ were $27.2,43.1$ and $42.9 \mu \mathrm{g} / \mathrm{ml}$, respectively. Its inhibitory effect did not increase at concentrations of 200 and $300 \mu \mathrm{g} / \mathrm{ml}$ (data not shown).

GlcNAc oligomer-specific lectin STA inhibited the histamine release induced by bradykinin and $\mathrm{PEI}_{6}$ (Fig. 1), $\mathrm{IC}_{30}$ values being 76 and $17.5 \mu \mathrm{g} / \mathrm{ml}$, respectively. The inhibitory effect of STA on histamine release induced by compound 48/80 was significant, but not strong enough to enable calculation of its $\mathrm{IC}_{30}$ value. STA effectively inhibited the histamine release induced by $\mathrm{PEI}_{6}$ with an $\mathrm{IC}_{50}$ value of $73.9 \mu \mathrm{g} / \mathrm{ml}$. GlcNAc $(30 \mathrm{mM})$ partially reversed the inhibition of histamine release induced by $\mathrm{PEI}_{6}$; percentages of inhibition by STA $(100 \mu \mathrm{g} / \mathrm{ml})$ in the absence and presence of GlcNAc $(30 \mathrm{mM})$ were $54.0 \pm 2.0(\mathrm{n}=8)$ and $34.5 \pm 2.7(\mathrm{n}=6, \mathrm{P}<0.01) \%$, respectively.

On the other hand, MAM and STA did not inhibit the histamine release induced by A23187. Percentages of histamine release inhibition induced by $\mathrm{A} 23187(1 \mu \mathrm{M})$ in the presence of MAM $(100 \mu \mathrm{g} / \mathrm{ml})$ and STA $(100 \mu \mathrm{g} / \mathrm{ml})$ were $-2.4 \pm 6.2(n=6)$ and $-18.3 \pm 9.8(n=6) \%$, respectively. The A23187 $(1 \mu \mathrm{M})$ induced histamine release from neuraminidase $\left(5 \times 10^{-4} \mathrm{U} / \mathrm{ml}\right)$-treated mast cells ( $\%$ inhibition $<2 \%$ ) was not significantly different from that of the untreated cells. On the other hand, the neuraminidase $\left(5 \times 10^{-4} \mathrm{U} / \mathrm{ml}\right)$ treatment of mast cells inhibited the histamine release induced by compound $48 / 80(0.3$ $\mu \mathrm{g} / \mathrm{ml})$ by $43.1 \pm 3.6(\mathrm{n}=6, \mathrm{P}<0.001) \%$.

\section{Compound $48 / 80$}

Bradykinin

$\mathrm{PEI}_{6}$

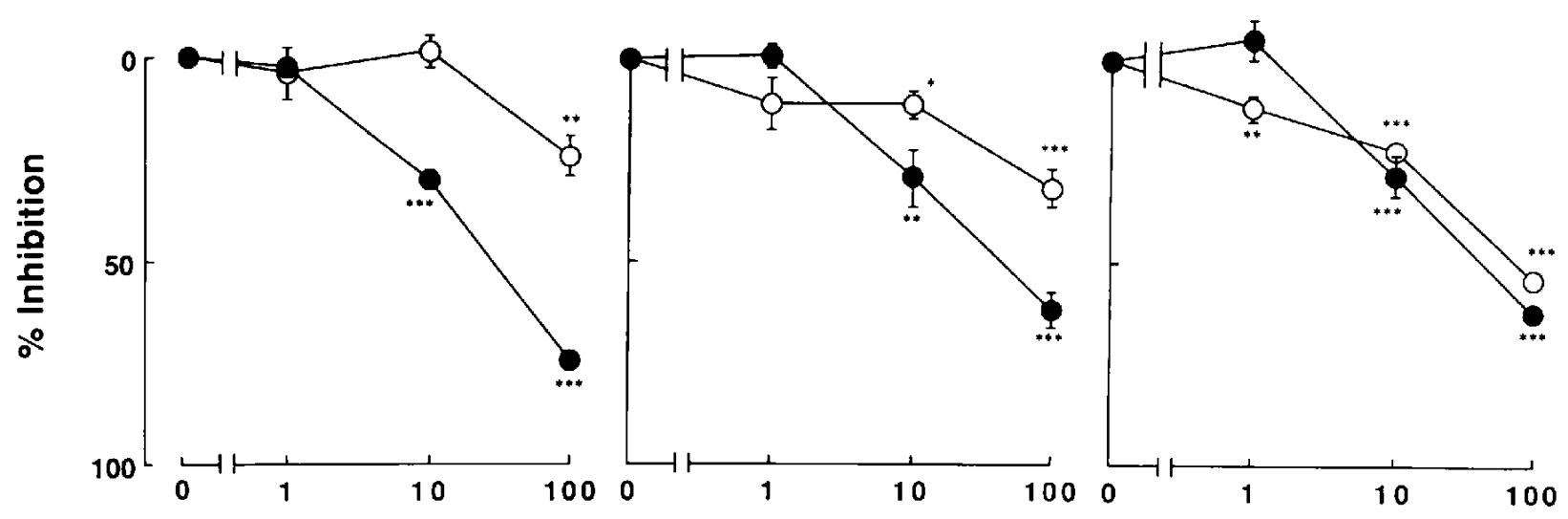

Lectin $(\mu \mathrm{g} / \mathrm{ml})$

Fig. 1. Effects of STA and MAM on histamine release induced by compound 48/80, bradykinin or PEI 6 . After preincubation with STA (open circles) or MAM (closed circles) for $10 \mathrm{~min}$, the mast cells were incubated with compound $48 / 80(0.3 \mu \mathrm{g} / \mathrm{ml})$, bradykinin $(50 \mu \mathrm{M})$ or $\mathrm{PEI}_{6}(3 \mu \mathrm{g} / \mathrm{ml})$ for $10 \mathrm{~min}$ at $37^{\circ} \mathrm{C}$. Percent inhibition was calculated as described in Materials and Methods. Values are given as the means $\pm \mathrm{S}$.E. for 6 to 8 replicate experiments. ${ }^{*} \mathrm{P}<0.05,{ }^{* *} \mathrm{P}<0.01,{ }^{* * *} \mathrm{P}<0.001$. 

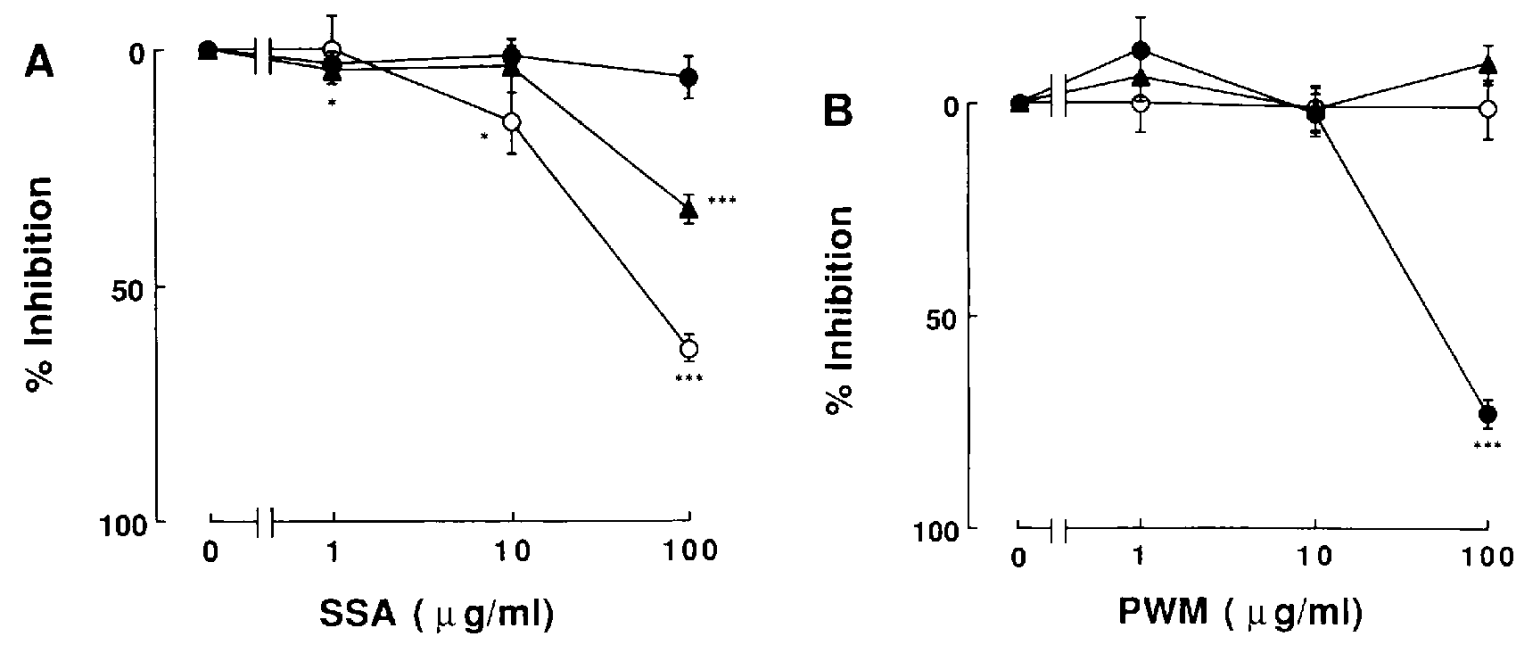

Fig. 2. Effects of SSA (A) and PWM (B) on histamine release induced by compound $48 / 80$, bradykinin or $\mathrm{PEI}_{6}$. After preincubation with SSA or PWM for $10 \mathrm{~min}$, the mast cells were incubated with compound $48 / 80(0.3 / \mathrm{g} / \mathrm{ml}$, open circles), bradykinin $\left(50 \mu \mathrm{M}\right.$, closed triangles) or $\mathrm{PEI}_{6}\left(3 \mu \mathrm{g} / \mathrm{ml}\right.$, closed circles) for $10 \mathrm{~min}$ at $37^{\circ} \mathrm{C}$. Percent inhibition was calculated as described in Materials and Methods. Values are given as the means \pm S.E. for 6 to 8 replicate experiments. ${ }^{*} P<0.05$, ${ }^{* * *} \mathrm{P}<0.001$.

Effects of SSA and PWM on the histamine release induced by compound $48 / 80$, bradykinin and $P E I_{6}$

Since MAM recognizes Sia $\alpha 2,3 \mathrm{Gal}$, we further examined the effects of SSA which is more specific for Sia $\alpha 2,6 \mathrm{Gal}$ than Sia $\alpha 2,3 \mathrm{Gal}$. SSA inhibited the histamine release induced by compound $48 / 80\left(\mathrm{IC}_{30}=19.6 \mu \mathrm{g} / \mathrm{mI}\right.$, $\left.\mathrm{IC}_{50}=53.0 \mu \mathrm{g} / \mathrm{ml}\right)$ and bradykinin $\left(\mathrm{IC}_{30}=75.1 \mu \mathrm{g} / \mathrm{ml}\right)$, but not that induced by $\mathrm{PEI}_{6}$ (Fig. 2A). On the other hand, the histamine release induced by $\mathrm{PEI}_{6}$ was significantly inhibited by the GlcNAc oligomer- and $N$-acetyl lactosamine-specific lectin $\mathrm{PWM}$ with an $\mathrm{IC}_{50}$ of 47.2 $\mu \mathrm{g} / \mathrm{ml}$, whereas those induced by compound $48 / 80$ and bradykinin were not inhibited (Fig. 2B). Preincubation of PWM with its inhibitory sugar, chitooligosaccharide, at

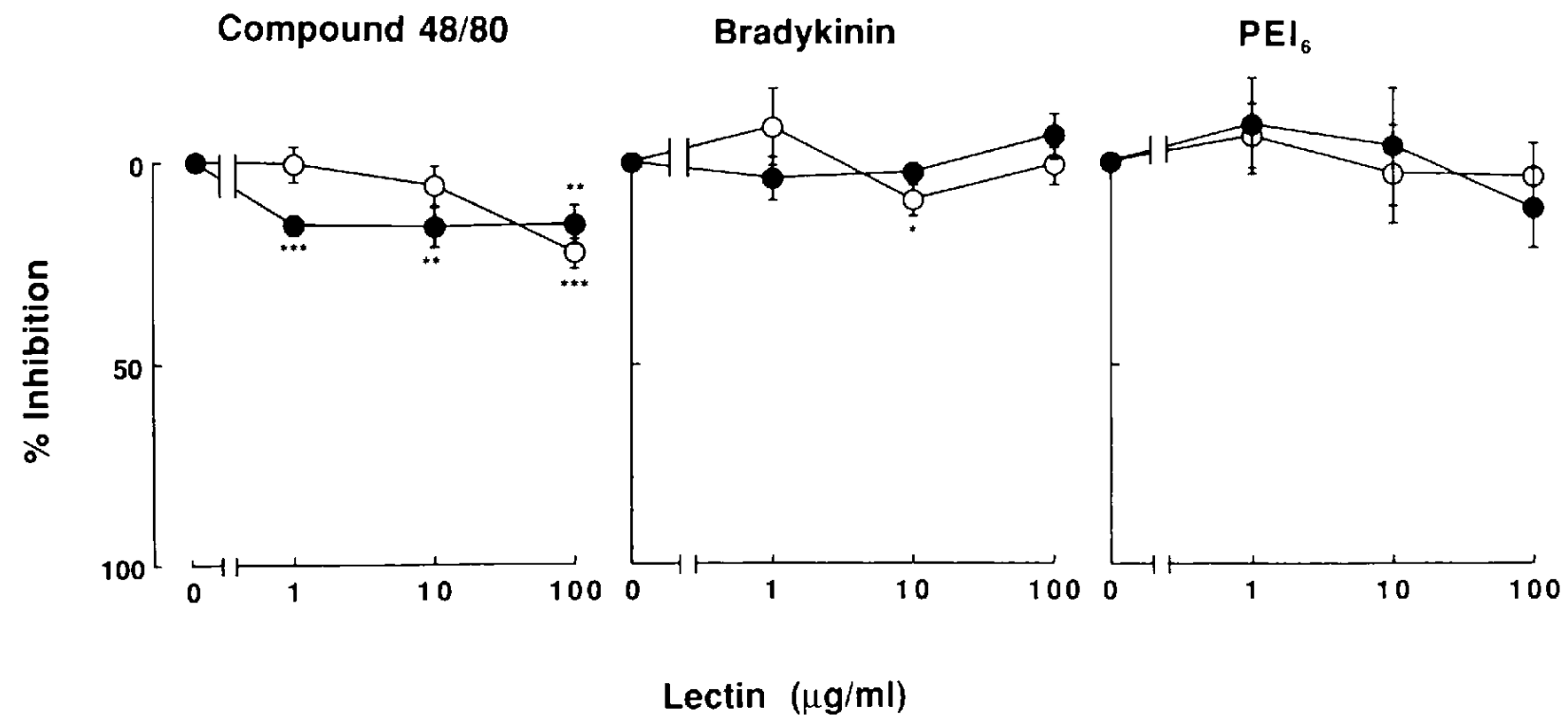

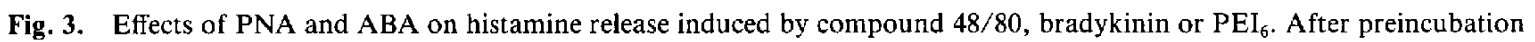
with PNA (open circles) or ABA (closed circles) for $10 \mathrm{~min}$, the mast cells were incubated with compound $48 / 80(0.3 \mu \mathrm{g} / \mathrm{ml})$, bradykinin $(50 \mu \mathrm{M})$ or $\mathrm{PEI}_{6}(3 \mu \mathrm{g} / \mathrm{ml})$ for $10 \mathrm{~min}$ at $37^{\circ} \mathrm{C}$. Percent inhibition was calculated as described in Materials and Methods. Values are given as the means \pm S.E. for 5 to 14 replicate experiments. ${ }^{*} \mathrm{P}<0.05,{ }^{* *} \mathrm{P}<0.01,{ }^{* * *} \mathrm{P}<0.001$. 


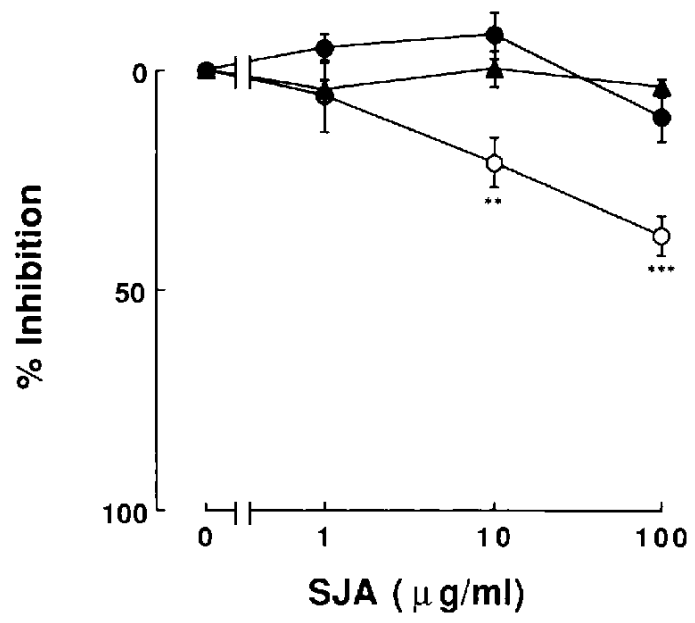

12

1
Fig. 4. Effects of SJA on histamine release induced by compound 48/80, bradykinin or $\mathrm{PEI}_{6}$. After preincubation with SJA for 10 min, the mast cells were incubated with compound 48/80 $(0.3$ $\mu \mathrm{g} / \mathrm{ml}$, open circles), bradykinin ( $50 \mu \mathrm{M}$, closed triangles) or $\mathrm{PEI}_{6}$ ( $3 \mu \mathrm{g} / \mathrm{ml}$, closed circles) for $10 \mathrm{~min}$ at $37^{\circ} \mathrm{C}$. Percent inhibition was calculated as described in Materials and Methods. Values are given as the means \pm S.E. for 6 to 8 replicate experiments. ${ }^{* *} \mathrm{P}<0.01$, ${ }^{* * *} \mathrm{P}<0.001$.

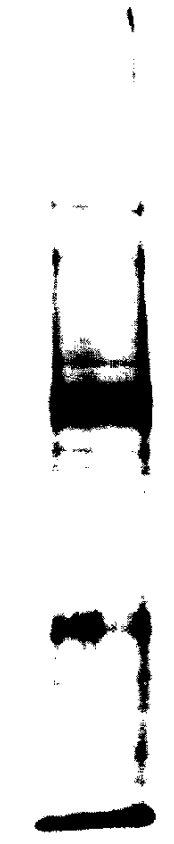

\section{$-205 \mathrm{~K}$}

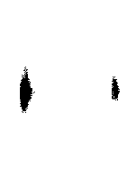

$116.5 \mathrm{~K}$

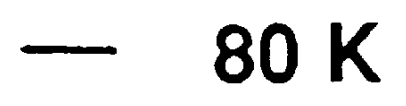

1

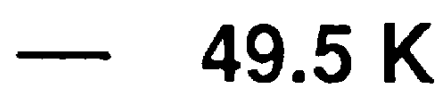

Fig. 5. Blotting analysis of glycoproteins from rat peritoenal mast cells having affinity to MAM. Glycoproteins were separated on a $7.5 \%$ acrylamide gel. Purified mast cells were incubated with neuraminidase $\left(10^{-2} \mathrm{U} / \mathrm{ml}\right)$ at $37^{\circ} \mathrm{C}$ for $1 \mathrm{hr}$ with gentle shaking. The cells were washed twice and resuspended in fresh HEPES-buffered Tyrode solution. Lane 1, glycoproteins from neuraminidase-untreated mast cells detected using biotinyl-MAM $(20 \mu \mathrm{g} / \mathrm{ml})$; lane 2, glycoproteins from neuraminidase-treated mast cells detected using biotinyl-MAM $(20 \mu \mathrm{g} / \mathrm{ml})$. 
the concentration of $1 \mathrm{w} / \mathrm{v} \%$ had no effect on the inhibition by PWM on the histamine release induced by $\mathrm{PEI}_{6}$, its percentage of inhibition being less than $1 \%$.

\section{Effects of lectins that bind mucin type oligosaccharides} on the histamine release induced by compound $48 / 80$, bradykinin and $P E I_{6}$

ABA and PNA slightly inhibited the histamine release induced by compound $48 / 80$ and had no appreciable effect on that induced by $\mathrm{PEI}_{6}$ (Fig. 3). PNA $(10 \mu \mathrm{g} / \mathrm{ml}$ ) inhibited the histamine release induced by bradykinin $(P<0.05)$, although not in a dose-dependent manner. The inhibitory effect of ABA on histamine release induced by compound 48/80 was also not dose-dependent (Fig. 3).

Moreover, SJA, which binds to both mucin type and asparagine-linked oligosaccharides, inhibited the histamine release induced by compound $48 / 80$ in a dose-dependent manner, its $\mathrm{IC}_{30}$ being $37.8 \% \mathrm{~g} / \mathrm{ml}$. On the other hand, SJA had no appreciable effect on the histamine release induced by bradykinin or $\mathrm{PEI}_{6}$ (Fig. 4).

\section{Analysis of rat mast cell glycoproteins witih affinity to MAM}

The glycoproteins of rat peritoneal mast cells were examined with biotinyl-MAM. Figure 5 shows that there are glycoproteins having affinity to MAM, and that the Siaresidues of these glycoproteins were eliminated by treatment of the mast cells with neuraminidase $\left(10^{-2} \mathrm{U} / \mathrm{ml}, 1\right.$ hr).

\section{Additive effects of compound $48 / 80$, bradykinin and $P E I_{6}$}

We examined the histamine release in the presence of different combinations of low concentrations of compound $48 / 80(0.1 \mu \mathrm{g} / \mathrm{ml})$, bradykinin $(20 \mu \mathrm{M})$ and $\mathrm{PEI}_{6}$ $(1 \mu \mathrm{g} / \mathrm{ml})$. The percentages of net histamine release induced by compound $48 / 80(0.1 \mu \mathrm{g} / \mathrm{ml})$, bradykinin $(20 \mu \mathrm{M})$ and $\mathrm{PEI}_{6}(1 \mu \mathrm{g} / \mathrm{ml})$ were $4.5 \pm 1.1(\mathrm{n}=8), 4.7 \pm 1.5(\mathrm{n}=5)$ and $10.7 \pm 1.5(\mathrm{n}=6) \%$, respectively. Spontaneous histamine release in these experiments was $6.1 \pm 0.4(n=18) \%$. Bradykinin $(20 \mu \mathrm{M})$ and compound $48 / 80(0.1 \mu \mathrm{g} / \mathrm{ml})$ together additively enhanced the net histamine release. The same effects were demonstrated with $\operatorname{PEI}_{6}(1 \mu \mathrm{g} / \mathrm{ml})$ and compound $48 / 80(0.1 \mu \mathrm{g} / \mathrm{ml})$ and with $\mathrm{PEI}_{6}$ (1 $\mu \mathrm{g} / \mathrm{ml})$ and bradykinin $(20 \mu \mathrm{M})$ (Table 1$)$.

\section{DISCUSSION}

Our group previously reported inhibitory effects of WGA and PHA-E ${ }_{4}$ on histamine release induced by nonimmunologic stimuli (17). In this study, we found that STA was also inhibitory, like WGA and $\mathrm{PHA}_{4}$ (Fig. 1). Since STA has an affinity to GlcNAc oligomers, it possibly binds to some of the glycoproteins with GlcNAc-
Table 1. Additive effects of three non-immunologic stimuli in different combinations on enhancement of histamine release

\begin{tabular}{lc}
\hline Non-immunologic stimuli & $\begin{array}{c}\text { Net histamine } \\
\text { release }(\%)\end{array}$ \\
\hline $\begin{array}{l}\text { Net histamine release } \% \text { induced } \\
\text { by compound } 48 / 80 \text { and bradykinin }\end{array}$ & $\begin{array}{c}6.3 \pm 0.9^{\mathrm{A}} \\
(\mathrm{n}=12)\end{array}$ \\
$\begin{array}{l}\text { Net histamine release } \% \text { induced by compound } 48 / 80 \\
+ \text { net histamine release } \% \text { induced by bradykinin }\end{array}$ & $\begin{array}{c}8.0 \pm 2.1^{\mathrm{B}} \\
(\mathrm{n}=6)\end{array}$ \\
$\begin{array}{l}\text { Net histamine release } \% \text { induced } \\
\text { by compound } 48 / 80 \text { and } \mathrm{PEI}_{6}\end{array}$ & $19.8 \pm 2.3^{\mathrm{C}}$ \\
Net histamine release $\%$ induced by compound $48 / 80$ & $13.5 \pm 3.2^{\mathrm{D}}$ \\
+ net histamine release $\%$ induced by PEI & $(\mathrm{n}=4)$ \\
$\begin{array}{l}\text { Net histamine release } \% 0 \text { induced } \\
\text { by bradykinin and PEI }\end{array}$ & $19.2 \pm 2.6^{\mathrm{E}}$ \\
Net histamine release $\%$ induced by bradykinin & $15.6 \pm 4.6^{\mathrm{F}}$ \\
+ net histamine release $\%$ induced by $\mathrm{PEI}_{6}$ & $(\mathrm{n}=3)$ \\
\hline
\end{tabular}

Histamine release was measured by the addition of two of the three non-immunologic stimuli simultaneously. The concentrations of compound $48 / 80$, bradykinin and $\mathbf{P E I}_{6}$ were $0.1 \mu \mathrm{g} / \mathrm{ml}, 20 \mu \mathrm{M}$ and $1 \mu \mathrm{g} / \mathrm{ml}$, respectively. Percentages of net histamine release induced by compound $48 / 80(0.1 \mu \mathrm{g} / \mathrm{ml})$, bradykinin $(20 \mu \mathrm{M})$ and $\mathrm{PEI}_{6}$ $(1 \mu \mathrm{g} / \mathrm{ml})$ were $4.5 \pm 1.1 \%(\mathrm{n}=8), 4.7 \pm 1.5 \%(\mathrm{n}=5)$ and $10.7 \pm 1.5 \%$ $(n=6)$, respectively. The spontaneous histamine release was $6.1 \pm 0.4 \%(\mathrm{n}=18)$. Differences between ${ }^{\mathrm{A}}$ and ${ }^{\mathrm{B}},{ }^{\mathrm{C}}$ and ${ }^{\mathrm{D}}$, and ${ }^{\mathrm{E}}$ and ${ }^{\mathrm{F}}$ were not significant.

residues that were detected by WGA- and $\mathrm{PHA}_{-} \mathrm{E}_{4}$-lectin blotting, as previously described (17). Inhibition by STA on the histamine release induced by $\mathrm{PEI}_{6}$ was sugarspecific, but inhibition by PWM on the histamine release induced by $\mathrm{PEI}_{6}$ was not (Fig. 2B), suggesting that the inhibitory mechanisms of STA and PWM were different. As PWM did not inhibit histamine release induced by compound $48 / 80$ and bradykinin (Fig. 2B), the interaction of PWM with the corresponding glycoproteins was not sufficient to prevent the mast cell activation. Among WGA, STA and PWM, each having an affinity to GlcNAc oligomers, WGA is the most potent inhibitor; its IC $_{50}$ values for inhibition of histamine release induced by compound 48/80, bradykinin and $\mathrm{PEI}_{6}$ were $160,41.4$ and $37.0 \mu \mathrm{g} / \mathrm{ml}$, respectively, as previously described (17).

Sia is involved in non-immunologic stimuli; neuraminidase-treated rat peritoneal mast cells lost their ability to respond to compound $48 / 80$, substance $P$, bradykinin and anaphylatoxins $(11,29,30)$. Inhibitory effects of MAM on the histamine release induced by compound 48/80, bradykinin and $\mathrm{PEI}_{6}$ but not that by A23187 (Fig. 1) suggest that binding of MAM to glycoproteins with Sia residues resulted in the inhibition of the histamine release induced by compound $48 / 80$, bradykinin and $\mathrm{PEI}_{6}$, but not that by A23187. The inhibitory potency of MAM was more than or almost the same as that of WGA (Fig. 1), suggesting that not only GlcNAc oligomers but also Sia are responsible for the inhibition by WGA. Inhibitory 
effects of MAM were consistent with the inhibitory effects of Limax flavus agglutinin (LFA), as previously reported (14). It is noteworthy that MAM inhibited the histamine release induced by $\mathrm{PEI}_{6}$, but SSA did not (Fig. 2A). Although both MAM and SSA have an affinity to Sia, the configurations recognized by the two were different. Sia $\alpha 2,3 \mathrm{Gal}$ seemed to be more important than $\operatorname{Sia} \alpha 2,6-$ Gal.

There are two possibilities to explain the inhibitory effects of MAM and STA. One is that the glycoproteins involved in the inhibition may contain both Sia and GlcNAc residues. Another is that the glycoproteins with Sia are different from the glycoproteins with GlcNAc oligomers. Our preliminary data showed that the inhibitory effect of MAM was not enhanced in the presence of STA, although MAM and STA recognize different sugar residues. The inhibition in the presence of both of MAM and STA was dependent on the inhibitory effect of MAM.

Lectins show mitogenic activities after 2 or 3 days incubation with lymphocytes (31). However, inhibition by lectins on the histamine release was observed in $10 \mathrm{~min}$ (Figs. 1-4). Our preliminary data showed that WGA and STA inhibited the histamine release induced by compound $48 / 80(0.3 / / \mathrm{g} / \mathrm{ml})$ in $1 \mathrm{~min}$, the $\%$ inhibition by WGA $(100 \mu \mathrm{g} / \mathrm{ml})$ and STA $(100 \mu \mathrm{g} / \mathrm{ml})$ being $54.7 \pm 3.7$ $(\mathrm{n}=6, \mathrm{P}<0.001)$ and $38.6 \pm 3.9(\mathrm{n}=10, \mathrm{P}<0.001) \%$, respectively. We also observed $45.1 \pm 5.0 \quad(n=6$, $\mathrm{P}<0.001) \%$ inhibition of the histamine release induced by compound $48 / 80$ by the addition of compound $48 / 80$ and WGA simultaneously. It was unlikely that the inhibitory effects depended on cell differentiation by these lectins.

The inhibitory lectins may interfere with the binding of the three non-immunologic stimuli to the specific glycoproteins. The additive effects of the three non-immunologic stimuli suggest that the action sites for compound $48 / 80$, bradykinin and $\mathrm{PEI}_{6}$ partially overlap each other.

The characteristics of the inhibitory effects of lectins on histamine release reflect the differences between compound $48 / 80$ and bradykinin. PEI $_{6}$ resembled bradykinin, except for the inhibitory effect of SSA. Compound 48/80 is, however, different from bradykinin and $\mathrm{PEI}_{6}$ with respect to its interaction with ABA and PNA (Fig. 3). SJA inhibited the histamine release induced by compound 48/80 (Fig. 4), as described by Bach and Brashler (25). We found that ABA, PNA and SJA were weak inhibitors of histamine release induced by compound $48 / 80$, as was Ricinus communis agglutinin $\left(\mathrm{RCA}_{120}, \mathrm{MW}=\right.$ $130,000)(17)$, suggesting that the mucin-type and asparagine-linked oligosaccharides possessing $\mathrm{Gal} / \mathrm{Gal}$ NAc residues and Gal $\beta 1,3 \mathrm{GalNAc}$ group on the rat mast cell membrane were important for mast cell activation by compound $48 / 80$, but not those by bradykinin and $\mathrm{PEI}_{6}$.
Compound 48/80, bradykinin and $\mathrm{PEI}_{6}$ partially shared the signalling pathways including Gi-like G protein. Based on the inhibitory effects of the lectins in this study, we proposed that one of the action sites for compound 48/80, bradykinin and $\mathrm{PEI}_{6}$ is glycoproteins having asparagine-linked-sugar residues composed of GlcNAc-oligomer, Sia (especially Sia $\alpha 2,3 \mathrm{Gal}$ ) and/or bisecting GlcNAc residues. In addition to Gi-like $\mathrm{G}$ proteins, these glycoproteins possibly play important roles in mast cell activation induced by non-immunologic stimuli.

The inhibitory effects of lectins demonstrated in this study were quite different from those effected by the binding of lectins to IgE molecules; in the latter case, lectins bound to sugar residues of IgE molecules instead of mast cell glycoproteins (32). Analyses using lectins revealed that the $\mathrm{PGE}_{1}$ receptor of mastocytoma P815 cells (33), substance $P$ receptor of porcine brain (34) and $\mathrm{M}_{2}$-muscarinic receptor of rat (35) were indeed glycoproteins. The lectin-specificities of these receptors differed from the mast cell glycoproteins involved in sugar-specific inhibition by lectins.

It is fortuitous that lectin-specific glycoproteins are one of the action sites for basic secretagogues so that the inhibitory lectins can be ultilized to determine these glycoproteins. We are currently examining lectin blotting using a lectin that has affinity to GlcNAc and releases histamine from rat peritoneal mast cells via Gi-like G protein (36). Comparison of glycoproteins specific for the inhibitory lectins with those specific for a lectin that releases histamine will give us useful information to clarify the mechanisms of non-immunologic stimuli via specific glycoproteins on rat peritoneal mast cells. Chemicals that control the functions of the glycoproteins would become helpful therapeutic tools to regulate immediate hypersensitivity.

\section{Acknowledgments}

The authors thank Drs. Naoto Oku (University of Shizuoka, Shizuoka) and Mamoru Nango (Nagoya Institute of Technology, Nagoya) for their kind gift of $\mathrm{PEI}_{6}$. We are grateful to Dr. Junken Aoki (Tokyo Metropolitan Institute of Medical Sciences, Tokyo) for his helpful advise. This work is supported in part by Godo Foundations of the Meiji College of Pharmacy.

\section{REFERENCES}

1 Irani, A.M.A. and Schwartz, L.B.: Mast cell heterogeneity. Clin. Exp. Allergy 19, 143-155 (1989)

2 Bienenstock, J.: An update on mast cell heterogeneity. J. Allergy Clin. Immunol. 81, 763-769 (1988)

3 Johnson, A.R., Hugli, T.E. and Muller-Eberhard, H.J.: Release of histamine from rat mast cells by the complement peptides C3a and C5a. Immunology 28, $1067-1080$ (1975)

4 Wuepper, K.D., Bokisch, V.A., Muller-Eberhard, H.J. and Stoughton, R.B.: Cutaneous responses to human C3 (third 
component of complement) anaphylatoxin in man. Clin. Exp. Immunol. 11, 13-20 (1972)

5 Paton, W.D.M.: A potent histamine liberator. Br. J. Pharmacol. 6, 499-508 (1951)

6 Devillier, P., Renoux, M., Giroud, J.P. and Regoli, D.: Peptides and histamine release from rat peritoneal mast cells. Eur. J. Pharmacol. 117, 89-96 (1985)

7 Lawman, M.A., Benyon, R.C. and Church, M.K.: Characterization of neuropeptide-induced histamine release from human dispersed skin mast cells. Br. J. Pharmacol. 95, 121 - 130 (1988)

8 Lawrence, I.D., Warner, J.A., Cohan, V.L., Lichtenstein, L.M., Kagey-Sobotka, A., Vavrek, R.J., Stewart, J.M. and Proud, D.: Induction of histamine release from human skin mast cells by bradykinin analogs. Biochem. Pharmacol. 38, $227-233$ (1989)

9 Suzuki-Nishimura, T., Sekino, H., Yoshino, Y., Nagaya, K., Oku, N., Nango, M. and Uchida, M.K.: Synthetic polycations, polyethylenimines and polyallylamines release histamine from rat mast cells. Jpn. J. Pharmacol. 51, 279-290 (1989)

10 Yamasaki, H. and Sugiyama, K.: Histamine release from isolated mast cells in metal ion-free medium. Jpn. J. Pharmacol. 22, $325-337$ (1972)

11 Mousli, M., Hugli, T.E., Landry, Y. and Bronner, C.: Mechanism of activation for anaphylatoxin C3a stimulation of mast cells. J. Immunol. 148, 2456-2461 (1992)

12 Nakamura, T. and Ui, M.: Simultaneous inhibitions of inositol phospholipid breakdown, arachidonic acid release, and histamine secretion in mast cells by islet-activating protein, pertussis toxin. J. Biol. Chem. 260, 3584-3593 (1985)

13 Bueb, J.L., Mousli, M., Landry, Y. and Bronner, C.: A pertussis toxin-sensitive $G$ protein is required to induce histamine release from rat peritoneal mast cells by bradykinin. Agents Actions 30, 98-101 (1990)

14 Yoshino, Y., Nagaya, K., Sekino, H., Uchida, M.K. and Suzuki-Nishimura, T.: Comparison of histamine release induced by synthetic polycations with that by compound $48 / 80$ from rat mast cells. Jpn. J. Pharmacol. 52, 387-395 (1990)

15 Regoli, D. and Nantel, F.: Direct activation of G proteins. Trends Pharmacol. Sci. 11, 400-401 (1990)

16 Mousli, M., Bueb, J.-L., Bronner, C., Rouot, B. and Landry, Y.: G protein activation: a receptor-independent model of action for cationic amphiphilic neuropeptides and venom peptides. Trends Pharmacol. Sci. 11, 358-362 (1990)

17 Suzuki-Nishimura, T., Nagaya, K., Matsuda, K., Uchida, M.K., Aoki, J., Umeda, M. and Inoue, K.: Sugar-specific inhibitory effects of wheat germ agglutinin and phytohemagglutinin- $\mathrm{E}_{4}$ on histamine release induced by basic secretagogues from rat peritoneal mast cells and their possible action sites. Jpn. J. Pharmacol. 57, $79-90$ (1991)

18 Allen, A.K. and Neuberger, A.: The purification and properties of the lectin from potato tubers. A hydroxy proline-containing glycoprotein. Biochem. J. 135, 307-314 (1973)

19 Irimura, T. and Nicolson, G.L.: Interaction of pokeweed mitogen with poly( $n$-acetyllactosamine)-type carbohydrate chains. Carbohydr. Res. 120, 187-195 (1983)

20 Wang, W.-C. and Cummings, R.D.: The immobilized leukoagglutinin from the seeds of Maackia amurensis binds with high affinity to complex-type Asn-linked oligosaccharides containing terminal sialic acid linked $\alpha-2,3$ to penultimate galactose residues. J. Biol. Chem. 263, 4576-4585 (1988)

21 Shibuya, N., Tazaki, K., Song, Z., Tarr, G.E., Goldstein, I.J. and Peumans, W.J.: A comparative study of bark lectins from three elderberry (Sambucus) species. J. Biochem. 106, $1098-1103$ (1989)

22 Kaifu, R. and Osawa, T.: Synthesis of $\alpha$ - $\beta$-D-galactopyranosyl(1-3)-o-(2-acetamido-2-deoxyl- $\alpha$ (and $\beta$ ) -D-galactopyranosyl- $N$ tosoyl-L-serine and their interaction with D-galactose-binding lectins. Carbohydr. Res. 69, 79-88 (1979)

23 Pereira, M.E.A. and Kabat, E.A.: Immunochemical studies on blood group LXII. Fractionation of hog and human A, H, and AH blood group immunoadsorbents of Dolichos and Lotus. J. Exp. Med. 143, 422-436 (1976)

24 Irimura, T., Kawaguchi, T., Terao, T. and Osawa, T.: Carbohydrate-binding specificity of the so-called galactose-specific phytohemagglutinins. Carbohydr. Res. 39, 317-327 (1975)

25 Bach, M.K. and Brashler, J.R.: Inhibition of IgE and compound $48 / 80$-induced histamine release by lectins. Immunology 29, 371-386 (1975)

26 Suzuki, T., Mori, K. and Uchida, M.: Inhibition by calcium influx of rat mast cells: Difference between induction of histamine release by concanavalin A and compound 48/80. Eur. J. Pharmacol. 85, 155-161 (1982)

27 Shore, P., Burkhalter, A. and Chon, V.: A method for fluometric assay of histamine in tissue. J. Pharmacol. Exp. Ther. 127, $182-186$ (1956)

28 Suzuki, T., Ohishi, K. and Uchida, M.: Effects of calmodulin inhibitor on histamine release from rat peritoenal mast cells induced by concanavalin A and ionophore A23187. Gen. Pharmacol. 14, 273-275 (1983)

29 Mousli, M., Bronner, C., Bueb, J.-L., Tschiehart, E., Gies, J.-P. and Landry, Y.: Activation of rat peritoneal mast cells by substance $P$ and mastoparan. J. Pharmacol. Exp. Ther. 250, 329-335 (1989)

30 Bueb, J.-L., Mousli, M., Bronner, C., Rouot, B. and Landry, Y: Activation of Gi-like proteins, a receptor-independent effect of kinins in mast cells. Mol. Pharmacol. 38, 816-822 (1990)

31 Lis, H. and Sharon, N.: Lectins as molecules and as tools. Annu. Rev. Biochem. 55, 35-67 (1986)

32 Shibasaki, M., Sumazaki, R., Isoyama, S. and Takita, H.: Interaction of lectins with human IgE: IgE-binding property and histamine releasing activity of twelve plant lectins. Int. Arch. Allergy Immunol. 98, 18-25 (1992)

33 Yatsunami, K., Fujisawa, J., Hashimoto, H., Kimura, K., Takahashi, S. and Ichikawa, A.: Effect of tunicamycin on functions of $\mathrm{PGE}_{1}$ receptors from mouse mastocytoma P-815 cells. Biochim. Biophys. Acta 1051, 94-99 (1990)

34 Liu, Y.F. and Quirion, R.: Presence of various carbohydrate moieties including $\beta$-galactose and $N$-acetyl glucosamine residues on solubilized porcine brain neurokinin-1/substance $\mathrm{P}$ receptors. J. Neurochem. 57, $1944-1950$ (1991)

35 Haddad, E.B., Landry, Y. and Gies, J.P.: Sialic acid residues as catalysts for $\mathbf{M}_{2}$-muscarinic agonist-receptor interactions. Mol. Pharmacol. 37, 682-688 (1990)

36 Matsuda, K., Uchida, M.K. and Suzuki-Nishimura, T.: Studies of IgE-independent receptor on rat peritoneal mast cells binding to Datura stramonium agglutinin. Jpn. J. Pharmacol. 61, Supp. I, 160P (1993) 